\title{
MEANINGLESSNESS IN LANGUAGE: THE CASE OF THE IGBO LANGUAGE
}

\author{
George E. Onwụdiwe* \\ http://dx.doi.org/10.4314/og.v13i 1.13
}

\begin{abstract}
Language as a means of communication conceives and transmits information. To perform this unique role, language should be devoid of any misconception. Language as speech and writing depends on some features to be relevant during communication exercise. Such features are today advertently or inadvertently mishandled, thus jeopardising this major function of language and thereby render the language meaningless. This paper investigates those factors which contribute to render language meaningless, especially in the Igbo language. The factors manifest both in speech and in writing the language; and they hinge on wrong pronunciation and spelling or wrong writing convention of the Igbo language. The causes of meaninglessness in Igbo language presented in this study include lack of knowledge of the form and mechanics of the language, poor or lack of training in the use of the language, both at home and in schools, lack of interest, the wave of the present trend of the (Igbo) youths in chasing foreign cultures at the detriment of the Igbo culture, lack of seriousness or lip service on the part of the government and other agencies as NGOs in promoting the Igbo language and culture. These findings therefore, will greatly help the students and teachers of language, particularly the Igbo language. Also, Igbo newscasters, preachers, traders, actors and actresses, businessmen and indeed all those literate in Igbo language and who use the language in their daily interaction will find the work useful. This will ultimately enhance communication in the language.
\end{abstract}

\section{Introduction}

Language is verbal and written expressions of the mind made to pass information. Language becomes meaningful when it expresses the mind of the user in such a manner that the content and context of the message is understood and the response of the recipient in congruence with the intent. This situation becomes possible only when the appropriate linguistic and paralinguistic features are 
applied and correctly too. Such features are suprasegments, pausing, correct pronunciation of speech sounds and observance of morphosyntactic and morphophonemic nuances of a language in speech which are germane for meaningful communication. In written language, mechanics of writing, including all the spelling rules, the morphology of the language, correct application of prosodic rules and the like are all that the user of a language must observe if the written exercise will serve the intended purpose of communication. These attributes do not preclude one being adequately knowledgeable in the language and competent in the use.

Today, people are too stylish in their use of language as if of ordinary fashion. They totally disregard the rules of the language, both the universal and the peculiar ones. This attitude has caused so many problems in communication, especially in such language as Igbo where many bask in ignorance in the rules of the language and their correct application and yet claim competence and expertise in speaking and writing it. They even go to the extent of formulating their own rules and pass them on to other uninformed users. This greatly hampers communication in the language today, whether in speech or in writing and goes further to destroy and relegate the language, as well as create disinterest in the scholars and users of the language, as well as the owners.

This unhealthy situation which affects language like Igbo and its use and function; and which renders it meaningless is the main focus of this paper. The data for the discussion were gathered mainly from Igbo newscasts and utterances from students of Nnamdi Azikiwe University, Awka. It is believed that identification and analysis of this malady will correct a great deal of the wrongs already caused the language in question and other languages and assuage the danger posed by this recklessness. In this way, the language will assume its proper position among other world languages and thus become more acceptable to the owners and other users.

\section{Language and Components of Language}

Language as a major distinguishing attribute of humans from other animals is one of the most regular activities man engages in. As asserted by Fromkin, Rodman and Hyams (2003:3), "we live in a world of language". At any time in our life, people talk - at home, in 
offices, in school, in the bus, in the market, at the mechanic workshop, in the field of play, etc. In other words, we are engaged in using language at all times, sometimes even in our sleep. This, therefore, posits that for meaningful existence and co-existence, man requires language. As Fromkin, Rodman and Hyams (2003) further state, "To understand our humanity, one must understand the nature of language that makes us human ... (as) only by the act of learning language does the child become a human being" (p.3).

Blake (2008:1) also posits: "Language enables us to describe a situation, including one that happened somewhere else at a previous time". For us to understand our existence and the context of our existence requires that we use language. Otherwise, we may not exist, or we may frequently fall into inexplicable problems. At least, language "is a major component of understanding human behaviour" (Harley, 1995:1). Hall (2005:4) clearly enunciates that language as either speech sound or text performs a great magic in life affairs. As he states: "In countless scenarios, the use of language yields new states of affairs in the world. Words literarily have the power to change the way the world is". Furthermore, he says, "we can think them, and see and hear their physical manifestation out in the world". Thus, he illustrates language and the components of language as below:

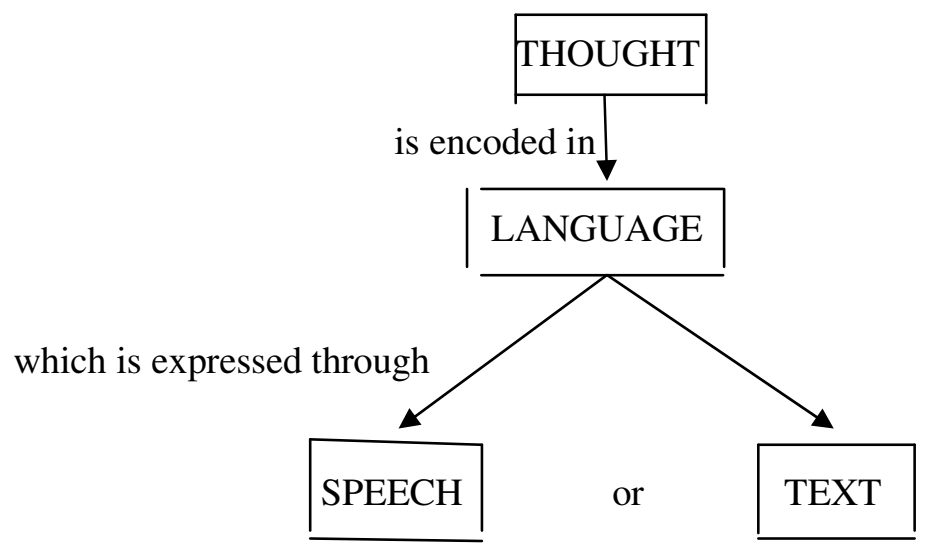

So, we are expected to know a language; and to know a language, we should have the ability to speak the language and express ourselves in writing in the language, and be understood by other 
Ọnwụdiwe: meaninglessness in language...

people who also know the language. This implies that we should have the capacity to produce sounds and letters which signify certain meanings and to understand or interpret the sounds and words/sentences produced by others.

Fromkin, Rodman, and Hyams (2003:4), describing linguistic knowledge say: "part of knowing a language means knowing what sounds (or signs) are in that language and what sounds are not". They also make it clear that knowledge of the sound system of a language includes more than knowing the inventory of sounds. But: "It includes knowing which sounds may start a word, end a word, and follow each other" (p.5). Therefore, knowledge of sounds and sound patterns in our language forms only a part of our linguistic knowledge. For, knowing a language is also to know that certain sound sequences signify certain concepts or meanings.

The argument of Fromkin, Rodman and Hyams (2003) above is that not only that language is human, or that it enables us to appreciate our existence and context of our existence (Harley, 1995 and Blake, 2008), we need to acquire adequate linguistic knowledge of language. This knowledge includes also knowledge of sound inventory and proper sequencing of the sounds (the phonology of the language) and, of course the orthography. Unfortunately, most users of some languages like Igbo language, including the native speakers take these requisite attributes for granted in their use of language. This often leads to misappropriation of the linguistic matrixes that make the language what it is and so ends up rendering the language meaningless.

\section{Language and Meaning}

It does not suffice in saying that language generates meanings; it is also very important to determine how language produces whatever meaning(s). For instance, the meaning may either arise from words in isolation, or concatenation of words of a language. In this manner, the meaning may simply be "iconic". In a situation like this, meanings of words are more obvious from the symbols provided; and this usually facilitates quick understanding by native speakers alike. But, when such social variables as "culture, social class, (and) even gender" (Winkler, 2007:132), are applied in understanding the interpretation of an utterance, meanings may no longer be as obvious as in the case of the iconic. Winkler (2007) refers to the types of 
meanings that result from the two situations described above as "logical" that is, used to define connotation and denotation, and "pragmatics". Whereas the logical meaning which she also calls literal meaning results from dictionary definition of words, pragmatic meanings result from constructions made within a particular culture.

Notwithstanding the above explanations, meanings of words are not certainly unambiguous even at the iconic level. Winkler (2007) argues that language is not an individual phenomenon for the expression of our internal dialogue, but rather a group phenomenon in that people use it to share information with one another. Therefore, she posits: "Words and meanings must be co-constructed by a group so that meaning can be shared. If each individual maintained widely different meanings for every word, communication would be impossible" (p. 133). This assertion corresponds to a similar one contained in the Whorfian hypothesis as enunciated in Carroll (1956) thus:

We dissect nature along lines laid down by our native languages... We cut,

Nature up, organize it into concepts, and ascribe significances as we do, largely because we are parties to an agreement to organize it in this way an agreement that holds throughout our speech community and is codified in the patterns of our language. The agreement is, of course, an implicit and unstated one, but its terms are absolutely obligatory; we cannot talk at all except by subscribing to the organization and classification of data which the agreement decrees (Whardhaugh, 1998, p. 217).

Here, we can add that apart from what we know of any language, other variables collectively known and accepted by the native speakers of the language together come into play before meaning can be construed from any utterance made with the words. These variables include culture. While culture refers to the pragmatic meanings derivable from words, the other two variables gender and social class constitute the main factors that affect 
Ọnwụdiwe: meaninglessness in language...

language so much so that we experience emergent varieties which result to different meanings most of which may either turn to be ambiguous or meaningless.

Furthermore, for language to generate desired meaning it is required that that language should be standardized. Ikekeonwu (1995:186) describes standardization of any language as a control in the midst of linguistic diversity. Thus, she says: "In the midst of linguistic diversity that is the lot of communities, countries and even families, there is always a 'steading hand' of standardization". She goes further to buttress her point with these words of Langacker (1973) on standardization:

The tendency of linguistic diversity to grow is checked by several factors.... Since a language is used primarily for communication, a speaker is not free to innovate without limit; his linguistic system must remain similar enough to the systems of the people around him to enable them understand him. Besides this essentially negative factor, a speaker is subjected to certain positive forces tending towards standardization.

Standardization helps to provide widely accepted dialects for use and enhances communication and creates checks for language use.

Another aspect of standardization necessary for our discourse is orthography. Both Williamson (1984) and Uba-Mgbemena (2011) discuss orthography and present principles of good orthography. According to Uba-Mgbemena, orthography is "a conventional or agreed way of writing a language using agreed symbols (letters) and abiding by agreed rules" (p. 1). He lists the following as constituents of orthography:

i) the symbols (letters) which should stand for individual sounds of the language.

ii) the rules for spelling the words of the language.

iii) the rules for indicating tones (if a tonal language),

iv) the rules for dividing words into syllables (syllabification), and

v) the rules for use of punctuation and capitalization. 
The above go to show that orthography is a prima facie ingredient of standardization and of good communication both in speech and in writing as is evidenced in the above constituents of orthography.

Williamson (1984) and Uba-Mgbemena (2011) both enunciate the principles of good orthography to include "accuracy", "consistency", "convenience", "harmonization' and "familiarity". Briefly explained, an orthography is deemed to possess the quality, accuracy if it agrees with the sound system of the language for which it is intended. For consistency, a letter must stand for only one symbol all through. When an orthography is difficult to type, write or print, it cannot be said to be convenient. Harmonization preaches for similarity to other orthographies, and familiarity advocates that an orthography should be as familiar as possible in appearance for easy identification. These characteristics of orthography are needed for meaningfulness of any language, otherwise it becomes meaningless.

\section{Meanings in Language}

Earlier in this discourse, we noted that language expresses meaning through different ways that may be logical or pragmatic. We also pointed out that in the performance of its major role of communication, language can be written or spoken. These are some avenues through which language operates to evoke meaning.

These meanings that language gives have been categorised into three by Cruse (2004:19) as "sentence meaning", "statement meaning", "utterance meaning". Simply explained, "sentence meaning" designates the semantic properties a sentence possesses merely by being a well-formed sentence before the question of context of use arises. According to him, this implies, "string of words of a particular type, whose well-formedness conditions are specific in the grammar of the language".

For the "statement meaning" Cruse (2004:22) continues: "We shall use the term statement meaning to refer to the combination of assertion and what is asserted in the literal, contextualized use of a declarative sentence". Cruse describes "utterance meaning" as what is produced in an act of linguistic communication, together with its intended meaning. These sheds of meaning are the avenues through which poor or wrong use of language determines the state of affairs in the world. Hence, Hall (2005:4) portends: 
The utterance of certain words by certain people can directly result in the bombing of Arab republic or the cessation of hostilities in a cluster of West African States, but a slightly different linguistic act can lead to the election of a new local government, the booking of a holiday for two, or the breakdown of a marriage.

By extension, meanings resulting from language can mar or make an event, which may result to confusing, deceiving, destroying, promoting, etc. when language is handled in either of the forms enumerated above.

Ordinarily, language, be it isolate words or sentences; be it spoken or written is required to perform the positive role of communication. But, contrarily, certain issues can bring about a reverse in the positive function of language and thus bring about meaninglessness. Cruse (2004) identifies some of these issues to include vagueness, dialect variation in language use according to speaker, which includes style of the language user.

At this juncture, let us distinguish between meaningfulness and meaninglessness which are the major concepts of this discourse. According to Ndimele (2001) a construction is said to be meaningful if the proposition it expresses is true. In other words, meaningfulness is judged by the truth value of a construction, whether oral or written.

For meaninglessness, Syal and Jindal (2010) in Ezenwafor (2014:3) enunciate the attributes of meaningless constructions to include, if the construction

- is not logical, i.e. if it is tautological (circular, not communicating anything)

- $\quad$ is contradictory (a false and absurd statement)

- does not correspond to real world knowledge (factual absurdity)

- violates some rules of lexical or grammatical combination.

Ezenwafor (2014) contributing in the explanation of meaninglessness says: "Meaninglessness is essentially a function of the incompatibility of certain semantic properties of certain words". She further says: "The meaningfulness and meaninglessness of an 
expression depends on the speaker's knowledge about the world". She continues: "This is to say that the speaker's knowledge of the world affects his choice of words" (pp.2 - 3). She, however, makes one point clear that meaningless expressions do not necessarily have to be grammatically odd. Ezenwafor's opinions here are clear affirmation of the Whorfian hypothesis and Carroll's assertion above.

In line with these assertions, Oruchalu (nd) presents the various greetings in the Igbo culture which he calls "fundamental greetings". In his presentations,

2)i (a) I bọola chi (Owerri area)

(b) I pụtakwara ụra? (Anambra)

(c) Maa mma (Okigwe)

(d) Kaa (Bende and Umuahia)

all serve as the English 'Good morning'. He, however, warns: "Note that the literal translation of 'Good morning' (Ezigbo ụtutụ) is not good Igbo".

For the afternoon, he gives these greetings

2)ii (a) Ndeewo (Owerri Area)

(b) Daalụ (Onitsha Area)

(c) Ma mma (Okigwe Area)

(d) Jọọwa (Afikp $\square$;

and at evening and night, he says that the greeting for the afternoon can suffice. "But when parting, that is when leaving anybody in the night, the following are used:

2)iii (a) Ka chi bọo (Good night to you)- singular

Ka chi bọọ nụ (good night to you all) - plural

(b) Ka chi fo (Good night to you) - singular

Ka chi fo nụ (Good night to you all) - plural. (Oruchalu, nd, pp. $5-7$ )

Of utmost importance to our discussion is this admonition by Oruchalu concerning greetings in Igbo: "It is entirely wrong to use these literal translations - "Ezigbo ututu, ezigbo ehihie, ezigbo mgbede, ezigbo anyasi for "Good morning, good afternoon, good evening, good night, respectively. Literally, they are correct but culturally they are wrong" (Oruchalu, nd, p. 7). Also very important to be added among these unaccepted greetings are the current varieties of these greetings which are: 'Ụtụtụ ọma' - G $\square \mathrm{d}$ m $\square$ rning; 
Ọnwụdiwe: meaninglessness in language...

'Ehihie ọma' - G $\square$ d aftern $\square \mathrm{n}$; ' $\square \mathrm{h} \llbracket \mathrm{r} \sqsubset$ chi ọma' - Good evening and Uchichi ọma - Good night.

These methods of greeting fall under the attribute of meaninglessness which Syal and Jindal describe as "factual absurdity" as they do not correspond to real world knowledge. These greetings clearly negate what Carroll refers to as agreement needed to be reached by a speech community.

\section{Different forms of emergent varieties of Meanings}

Linguistically, meaning is encoded through spoken and written words. Further still, it may be transmitted through gaze, gesture and other symbolic forms of communication. This paper is, however, concerned with the spoken and written forms of language. In any of these varieties, meaning can be positively transmitted, stalled or distorted, thus leading to meaninglessness. Hence, Winkler (2007:135) contends that such a situation poses a philosophical question about meaning thus: "Is the meaning of a message what the sender intends, what the receiver interprets, or both?"

Winkler continues her argument and says that a message could be itself challenged to a point that will be impossible for the receiver to interpret. Illustrating her point she says:

A monolingual English-speaking tourist had somehow ended up at a village grocery store where no one spoke English. The tourist was speaking very very slowly and was practically yelling the word bread. The unfortunate monolingual Spanish-speaking Dominican behind the counter was trying to help but did not have a clue as to what this ridiculous man wanted.

Such a challenge as illustrated above could be drawling a word to a point that the meaning becomes impossible to encode. In a kind of situation as above, Winkler slams: "If meaning is in the transmission of a message, there is no meaning here". Although the case of the monolingual English-speaker illustrated here can be viewed with some kind of pity, similar situations also abound when people turn to being unnecessarily stylish in uttering words or in speech generally or in writing or spelling of words. Worst cases are found among 
those people who either want to sound 'educated' but are themselves not very competent in the language, especially English language.

Other culprits in this behaviour are those people who are convinced that they are not proficient in a language, but pride and illiteracy will not allow them to control and hide their ignorance. This class of language users will instead formulate their own words and expressions. They also recklessly introduce their own forms of pronunciations, including strange pitch patterns, colorations and other prosodies. This kind of behaviour rather brings about confusion, or utter meaninglessness.

Among the emergent varieties of language are those arising from people who, on their own formulate words or change the phonology and the spelling rule of a language. Such variety is often times caused by unconventional stylishness, illiteracy and ignorance. Coupland (2007) describes the situation as "decontextualisation and transportability of performed speech". He states that the emergent vernaculars from this scenario which he tags "exposed dialects" are formulated and disseminated by groups of adolescent school kids and "they can rapidly reach awareness and some level of usage at a national level, and sometimes they can be close to global" (p.171). Coupland identifies the mass media as the major custodian of this trend, while product marketing through TV advertisements and contemporary TV comedy shows are the main facets for their promotion. This revelation by Coupland is evidenced in many unconventional words and slogans created and used by the mass media, most of which hamper communication to the majority.

In Igbo language, for instance, Onwudiwe (2015) identifies anglicizing of names in spelling and in pronunciation, wrong syllabification of words, wrong or poor observance of nuclear tones, wrong transfer of elements of second language to mother tongue or first language or interference of it as some of the reasons for poor performance in language. All these, if not checked will lead to meaninglessness and will stall communication.

\section{Aspects of Meaninglessness in the Igbo Language}

Igbo language is a tone language, and one of the major Nigerian languages. Igbo language is of Niger-Congo family and BenueCongo phylum. According to Ladefoged (2006), tone is a variation of pitch used to convey lexical information. In other words, tone 
Ọnwụdiwe: meaninglessness in language...

helps to distinguish meanings of words in the Igbo language; hence, Pike (1948:3) earlier contends: "When pitch is lexical, it distinguishes the meanings of words". Similarly, Richards and Schimidt (2002:555) define a tone language as "a language in which the meaning of a word depends on the tone used when pronouncing it". Though a non-segmental or prosodic feature, tone becomes apparently segmental when applied to segments in writing.

Apart from its lexical function, Mbah and Mbah (2010) in Onwudiwe (2015) note that tone also performs grammatical functions such as distinguishing between interrogative and declarative statements, distinguishing a sentence and a noun phrase containing a relative clause, distinguishing nouns in associative constructions from possessive construction, etc. The above are some of the features and characteristics of tone which if noted and observed in the Igbo speech enables the language function positively.

Meaninglessness in the Igbo language has been identified to traverse both speech and writing, but it appears most rampant is speech. Under speech, users of the language have been discovered to commit this offence through wrong application of suprasegmentals, pronunciation, speech style, illiteracy, self-esteem/pride, foreign influence, dialectal interference, etc, while in writing, they commit the offence in spellings, borrowings, writing conventions, codemixing, unconventional abbreviations or acronyms, wrong/poor translation (transliteration), wrong grammar, etc. This paper shall attempt to illustrate these issues with the data collected from various sources as mentioned above under different tables.

\section{Table 1: Meaninglessness in Speech/Pronunciation}

\begin{tabular}{|c|c|c|c|}
\hline Causes & Examples & $\begin{array}{l}\text { Standard } \\
\text { Form }\end{array}$ & of Data \\
\hline $\begin{array}{l}\text { 3. Speech } \\
\text { habit/style; } \\
\text { Illiteracy; } \\
\text { Ignorance; Self- } \\
\text { esteem/pride; } \\
\text { Foreign } \\
\text { influence/been- }\end{array}$ & $\begin{array}{l}\text { * gbàsárá } \\
\text { *Ézèọ́dịlị } \\
\text { (name) } \\
\text { * Ọ dịghị ihe } \\
\text { obụla goșịị ! } \\
\text { * } \underline{\hat{A}} \text { kọwago } \\
\text {... }\end{array}$ & $\begin{array}{l}\text { * gbásárá } \\
\text { *Ézèọ́dịlị } \\
\text { (name) } \\
\text { * Ọ dịghị ihe } \\
\text { ọbụla gosịní } \\
\text { * Á kọwago } \\
\text {... }\end{array}$ & $\begin{array}{l}\text { Students/Radio } \\
\text { news } \\
\text { Name of person } \\
\text { Students } \\
\text { Radio news } \\
\text { Radio House }\end{array}$ \\
\hline
\end{tabular}


Ogirisi: a new journal of African studies vol. 132017

\begin{tabular}{|l|l|l|l|}
\hline $\begin{array}{l}\text { to; Dialectal } \\
\text { interference; etc. }\end{array}$ & $\begin{array}{l}* \quad \text { Ésówúné } \\
\text { (name) } \\
* \text { Émēnákà } \\
\text { (name) }\end{array}$ & $\begin{array}{l}* \text { Ésòwùnè } \\
\text { (name) } \\
* \text { Éménáká } \\
\text { (name) }\end{array}$ & Radio news \\
& & & \\
\hline
\end{tabular}

As pointed out above, the examples are instances of meaninglessness caused by the factors listed above but most importantly, ignorance in the correct application of suprasegmentals, especially tone marks in Igbo.

Table 2: Meaninglessness in Spelling/Mechanics

\begin{tabular}{|c|c|c|c|}
\hline Causes & Examples & $\begin{array}{l}\text { Standard } \\
\text { Form }\end{array}$ & $\begin{array}{ll}\text { Source } \\
\text { Data }\end{array}$ \\
\hline $\begin{array}{l}\text { 4. Illiteracy; Ignorance; } \\
\text { Foreign } \\
\text { Influence/been-to; } \\
\text { Codemixing; } \\
\text { Unconventional } \\
\text { abbreviation/acronyms; } \\
\text { etc. }\end{array}$ & 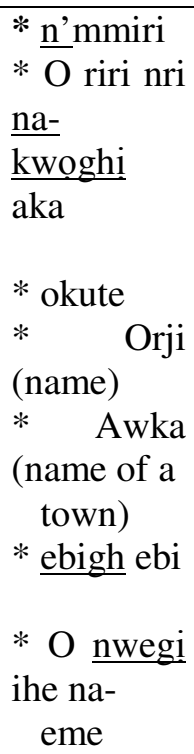 & $\begin{array}{l}\text { * na mmiri } \\
* \text { O riri nri } \\
\text { n'akwoghi } \\
\text { aka } \\
\text { * okwute } \\
* \quad \text { Oji } \\
\text { (name) } \\
* \quad \text { Oka } \\
\text { (name of a } \\
\text { town) } \\
\text { ebi ebighi } \\
* \text { O nweghi } \\
\text { ihe na- } \\
\text { eme }\end{array}$ & $\begin{array}{l}\text { Students } \\
\text { Students/news } \\
\text { translators } \\
\text { Old literature } \\
\text { Name of } \\
\text { person } \\
\text { Name of a } \\
\text { town } \\
\text { Bible Igbo, } \\
\text { literature } \\
\text { Students }\end{array}$ \\
\hline
\end{tabular}

Meaningless statements as exemplified above are most evident in writings of students and general public, particularly those who take it that writing Igbo does not require study and competence. 
Ọnwụdiwe: meaninglessness in language...

Table 3: Meaninglessness in the syntax, semantics and morphology

\begin{tabular}{|c|c|c|c|}
\hline Causes & Examples & $\begin{array}{l}\text { Standard } \\
\text { Forms }\end{array}$ & $\begin{array}{ll}\text { Source } \\
\text { Data }\end{array}$ \\
\hline $\begin{array}{l}5 . \quad \text { Wrong } \\
\text { arrangement of } \\
\text { words; Wrong } \\
\text { words; Wrong } \\
\text { choice } \\
\text { words; of } \\
\text { Illiteracy; } \\
\text { Ignorance; } \\
\text { Codemixing; } \\
\text { Dialectal } \\
\text { interference; etc }\end{array}$ & 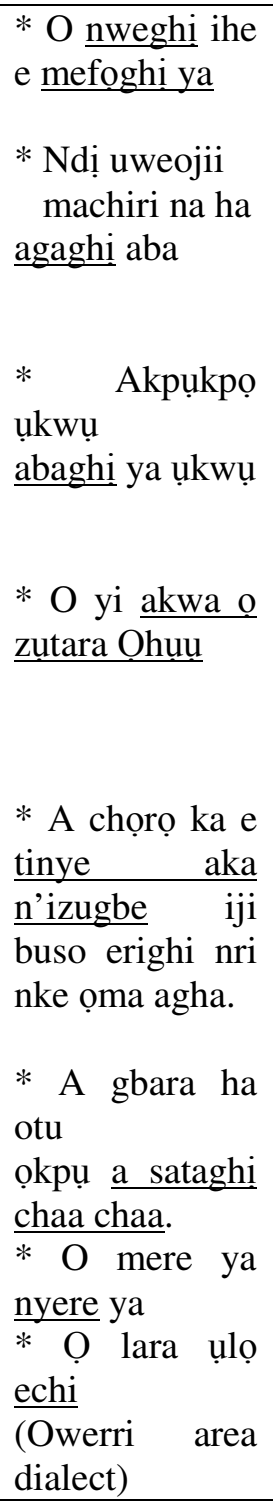 & 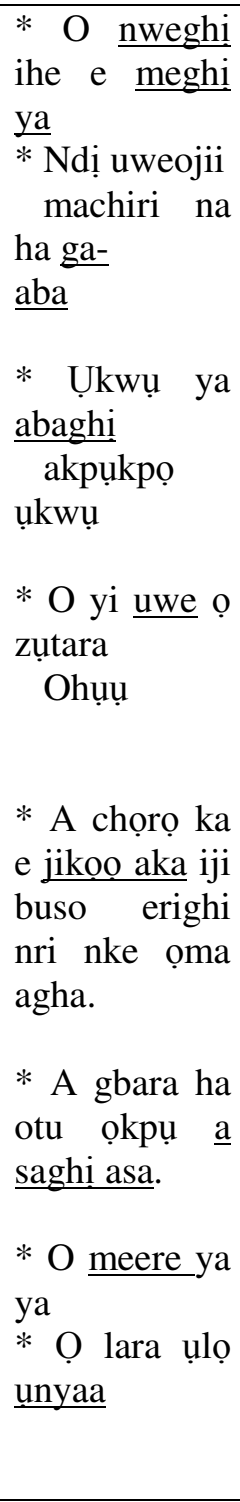 & $\begin{array}{l}\text { Students; } \\
\text { broadcaster } \\
\text { media; general } \\
\text { public } \\
\text { Students; } \\
\text { general public } \\
\text { Students; } \\
\text { general public; } \\
\text { broadcaster } \\
\text { media. } \\
\text { Broadcast } \\
\text { media }\end{array}$ \\
\hline
\end{tabular}


Ogirisi: a new journal of African studies vol. 132017

\begin{tabular}{|l|l|l|l|}
\hline & $\begin{array}{l}* \text { me eme ee } \\
\text { (Nnewi area } \\
\text { dialect) } \\
* \text { Ọgaghi me } \mathrm{maa} \\
\text { (Iheọchiọwa } \\
\text { dialect) }\end{array}$ & $*$ Ọ gaghi eri & \\
\hline
\end{tabular}

Igbo language, as other languages of the world has its standard structure and mechanics. Any deviation from that may lead to confusion or utter meaninglessness.

Table 4: Meaninglessness in Translation/Transliteration

\begin{tabular}{|c|c|c|c|}
\hline Causes & Examples & $\begin{array}{l}\text { Standard } \\
\text { form }\end{array}$ & $\begin{array}{l}\text { Source of } \\
\text { Data }\end{array}$ \\
\hline $\begin{array}{l}6 . \\
\text { Igbonzation; } \\
\text { Foreign } \\
\text { influence; } \\
\text { Ignorance; } \\
\text { Illiteracy; } \\
\text { Dialectal } \\
\text { interference; } \\
\text { etc. }\end{array}$ & 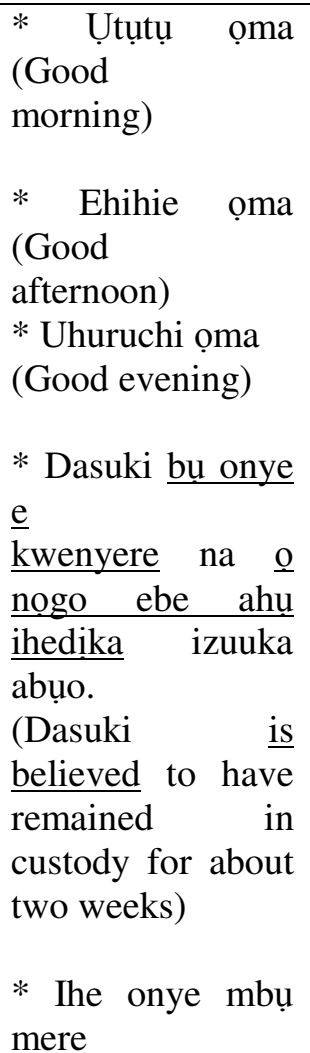 & $\begin{array}{l}\text { * Ị bọọla chi?/!̣ } \\
\text { pụtakwara ụra? } \\
\text { (Good } \\
\text { morning) } \\
* \quad \text { Ndeewo } \\
\text { (Well } \\
\text { done) } \\
* \quad \text { Ndeewo } \\
\text { (Well } \\
\text { done) } \\
\text { * O doro anya } \\
\text { na } \\
\text { Dasuki anọọla } \\
\text { na njichi/nchedo } \\
\text { ihe dị ka } \\
\text { izuụka abụọ. }\end{array}$ & $\begin{array}{l}\text { Media } \\
\text { workers; } \\
\text { Student; } \\
\text { General } \\
\text { public. }\end{array}$ \\
\hline
\end{tabular}




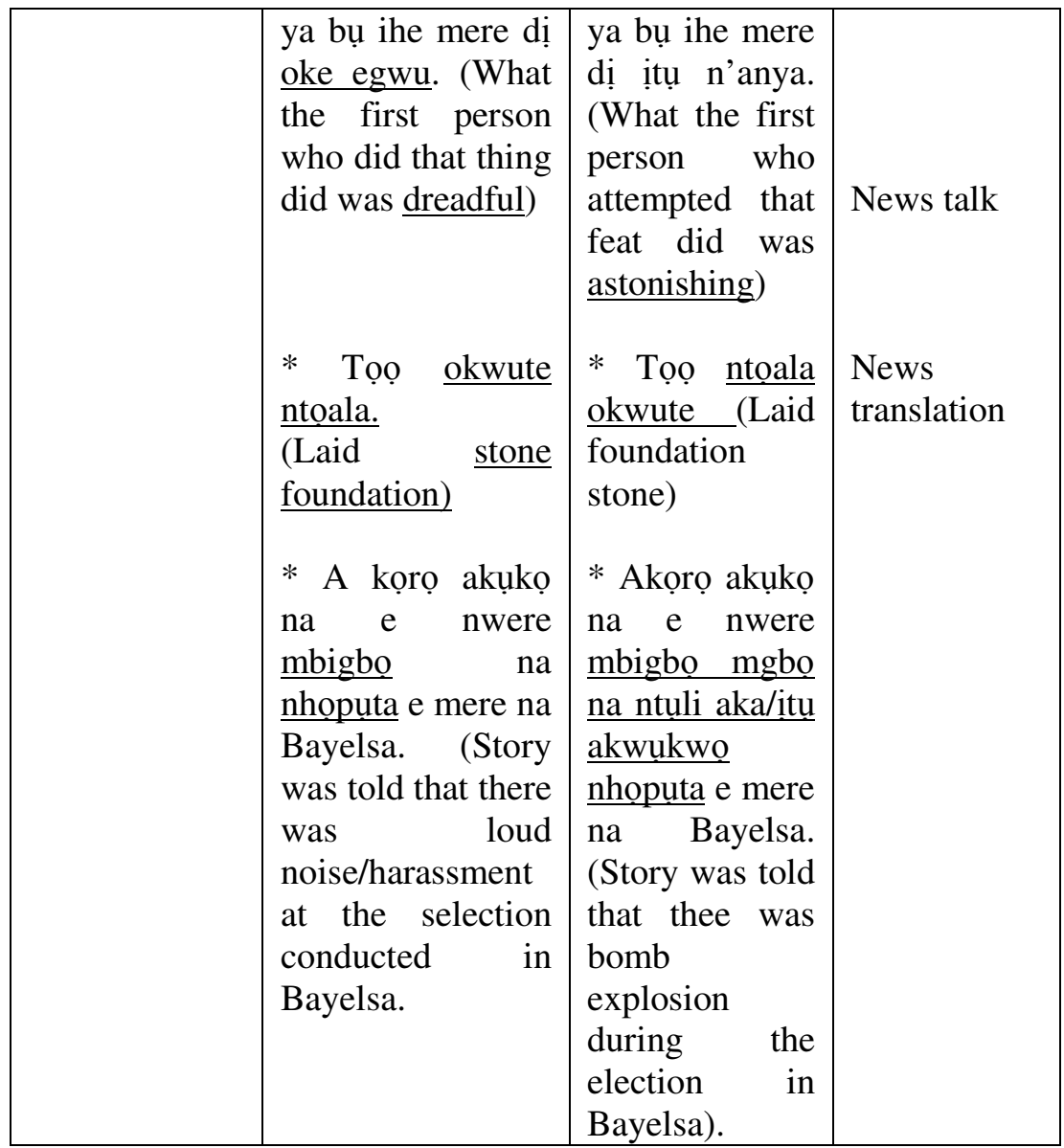

The above illustrations are indications of meaningless translations/transliterations that lead to confusion or communication collapse, especially practised and perpetuated by our media (workers).

Table 5: Meaningless due to General or Miscellaneous factors

\begin{tabular}{|l|l|l|l|} 
Causes & Examples & Standard Form & $\begin{array}{l}\text { Sources } \\
\text { of Data }\end{array}$ \\
\hline
\end{tabular}




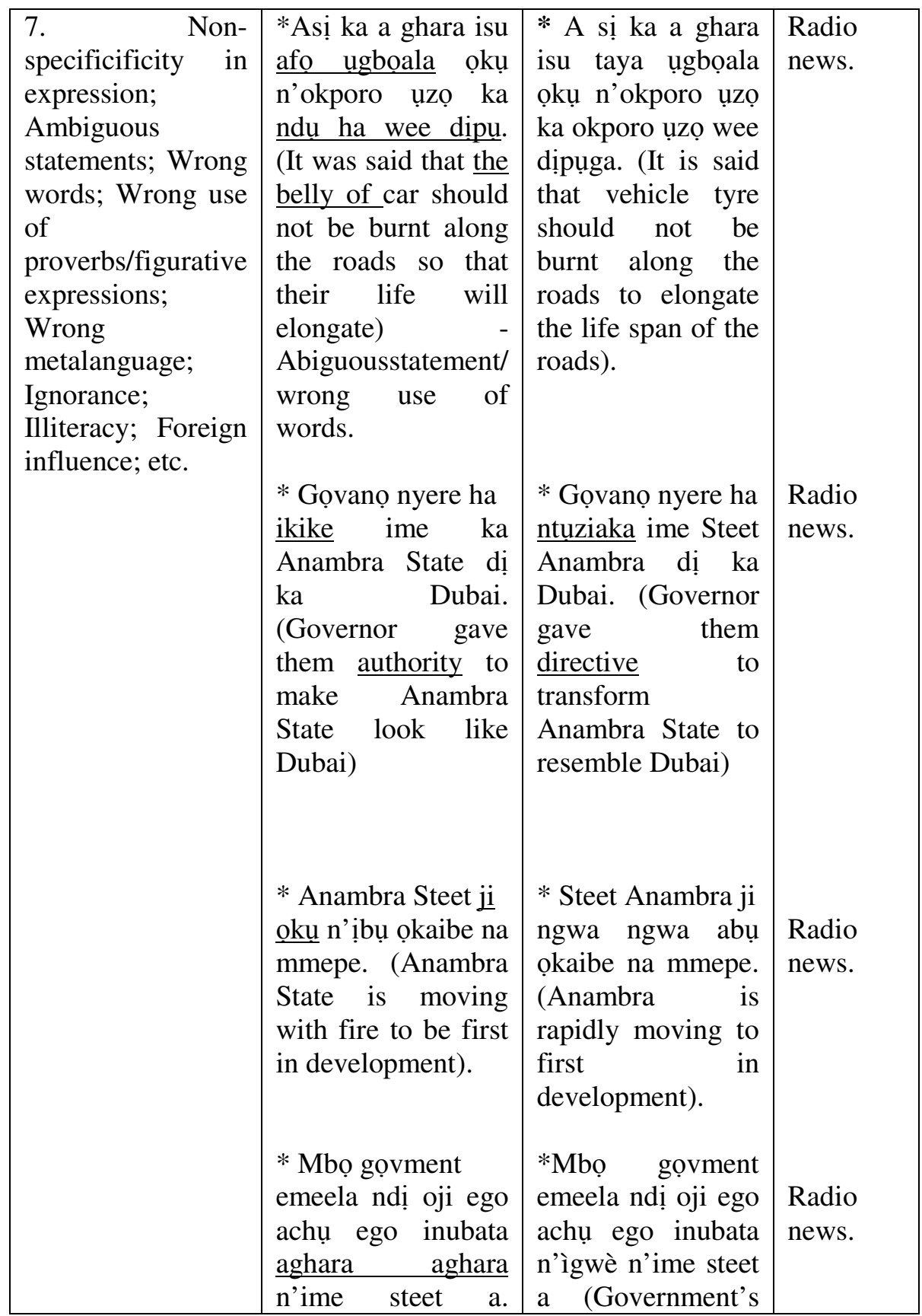




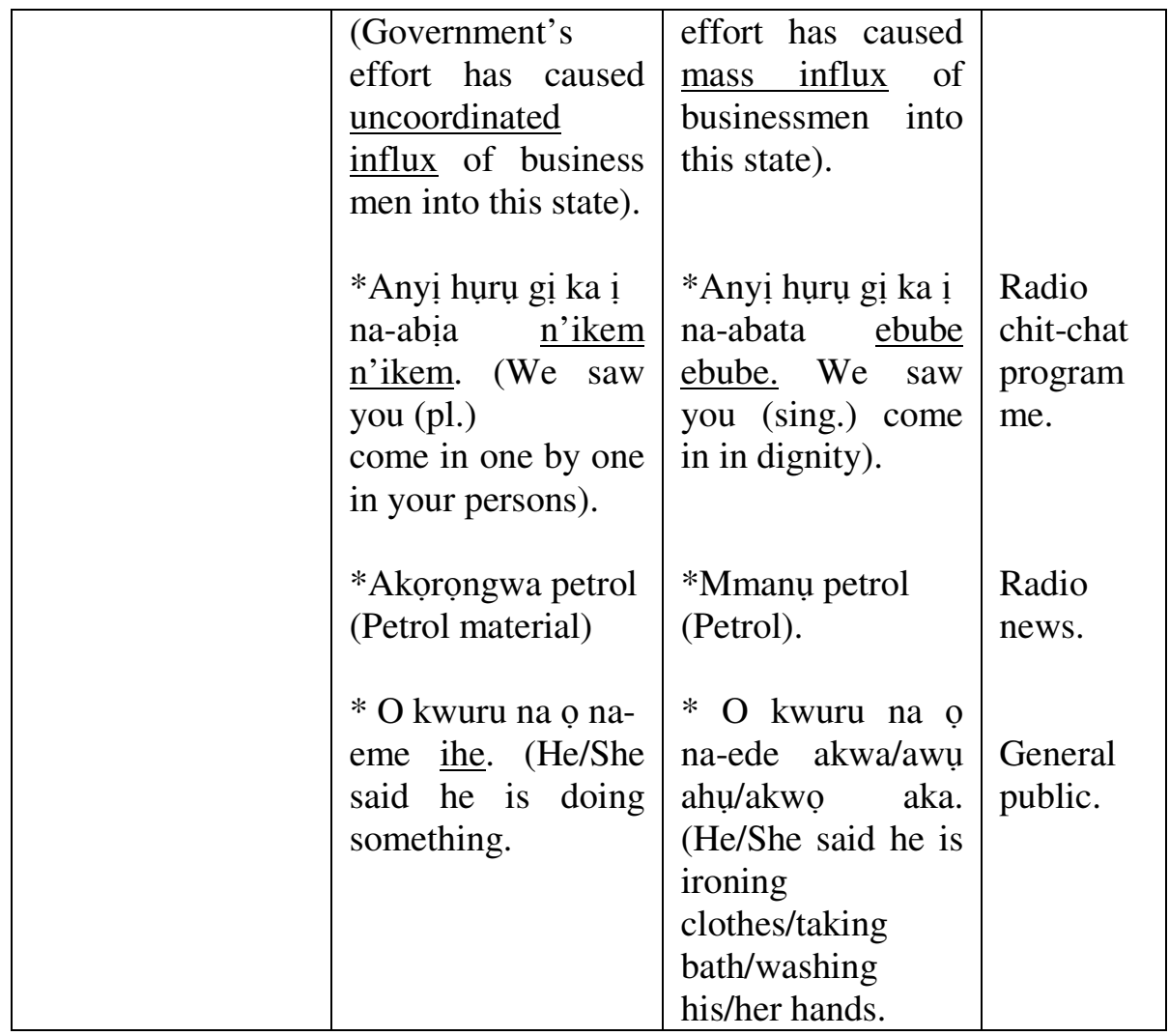

This Table presents only very few of what we have tagged miscellaneous factors that bring about confusion and meaninglessness in the language of study as in other languages. This Table is an omnibus one and it houses all that can be said to bring about confusion and meaninglessness, apart from the ones discussed in the preceding Tables.

\section{Conclusion}

Language is used solely to disseminate information. When this is carried out successfully communication is said to have taken place. Otherwise, communication will be stalled and human interaction and co-existence will be impossible. Hence, Hall (2005) notes that language is thought encoded and transmitted as speech or writing. 
What is to be transmitted is what the owners and users of the language collectively agreed upon evolving from the culture of the people. Therefore, for any language and user to perform, they must be well rooted in the people's culture, irrespective of the background of the user. Again, it is a prerequisite to be very competent in the various characteristic features of any language, such as language type and its varieties, especially the standard variety.

To perform well in Igbo language therefore, requires that we should understand tone and features and functions of tone. We also need to be competent in the phonology, syntax orthography, morphology and mechanics of Igbo. These will aid any user in communicating meaningfully in the language.

Unfortunately, this study has exposed that the cause of poor communication in Igbo is a consequent of several factors, prominent of illiteracy, foreign influence, ignorance, pride, dialectal interference. Other factors are imposition of foreign language on Igbo, unconventional abbreviation and acronyms, non-specific statements, wrong use of and choice of words, lack of knowledge or adequate knowledge of suprasegmentals, wrong use of proverbs and other figures of speech, wrong translation or transliteration, among numerous other consequences.

The study also identified the youths/students as those who ought to promote the use of the language, but who unfortunately do not show adequate commitment towards its correct use. The other group, the media workers are discovered to be worse off in using the language; and they are in the vantage position to promote or kill the language as noted by Coupland (2007) who observed that they falter due to being unnecessarily stylish thereby failing in their duty to communicate effectively.

In conclusion, this paper is an inroad into the causes of ineffective communication. It will benefit all linguists, journalists, students, teachers and the public and will help in developing Igbo and other languages. More studies of this nature are hereby strongly recommended.

*George Onwudiwe, Department of Igbo, African and Asian Studies. Nnamdi Azikiwe University, Awka.

elogee2002@gmail.com 
Ọwụdiwe: meaninglessness in language...

\section{References}

Blake, Barry J. (2008). All About Language. Oxford: Arnold.

Carroll, J. B. (1956). Language, Thought, and Reality: Selected Writings of Benjamin Lee Whorf. Cambridge, Mass: MIT Press.

Coupland, Nikolas (2007). Style: Language Variation and Identity. Cambridge: University Press.

Cruise, Alan (2004). Meaning in Language. Cambridge: University Press.

Ezenwafor, Chibunma Amara (2014). "Language Creativity and the Concept of Meaningfulness and Meaninglessness", Paper presented at Kay Williamson Legacy Lecture/Ndimele Symposium, University of Port Harcourt.

Fromkin, Victoria, Rodman, Robert \& Hyams, Nina (2003). An Introduction to Language. Wadsworth: Thomson.

Hall, Christopher J. (2007). An Introduction to Language and Linguistics. London: Continuum.

Harley, Trevor A. (1995). The Psychology of Language. East Sussex: Psychology Press.

Ikekeonwu, C. I. (1995). "Conventionalism and Pragmatism in Igbo Standardisation" in A. E. Afigbo (Ed.), F. C. Ogbalu and the Igbo Language. Onitsha: Varsity Industrial Press.

Ladefoged, Peter (2006). A Course in Phonetics. Wadsworth: CENGAGE Learning.

Langacker, R.W. (1973). Language and Its Structure. New York: Hrcourt Brace Jovanovich Inc.

Mbah, B. M. \& Mbah, E. E. (2010). Topics in Phonetics and Phonology: Contributions from Igbo. Nsukka: AP Express Publishers.

Ndimele, O. M. (2001). Readings in Language. Port Harcourt: M \& $\mathrm{J}$ Grand Orbit Communication.

Onwudiwe, George E. (2015). "Tone Intonation Interface: An Acoustic Analysis of Igbo Language Speakers of English", A PhD Dissertation of Nnamdi Azikiwe University, Awka.

Oruchalu, S. U. (nd). Igbo for Beginers. Ihiala: Deo Gratias Press. Pike, K. L. (1948). Tone Languages. An Arbor: The University of Michigan Press.

Richards, J. C. \& Schimidt, R. (2002). Longman Dictionary of Language Teaching and Applied Linguistics. London: Longman. 
Syal \& Jindal, D. V. (2010). An Introduction to Linguistics: Language, Grammar and Semantics. New Delhi: PIII Learning Private.

Ưba-Mgbemena, Asoonye (2011). Orthography: The Igbo Example. Lagos:Sam Iroanusi Publications.

Whardhaugh, Ronald (1998). An Introduction to Sociolinguistics. Oxford: Blackwell Publishers.

Williamson, Kay (1984). Practical Orthography in Nigeria. Ibadan: Heinemann Educational Books.

Winkler, Elizabeth G. (2007). Understanding Language. London: Continuum. 